\title{
Immunohistochemical discrimination of wild-type EGFR from EGFRvIll in fixed tumour specimens using anti-EGFR mAbs ICR9 and ICRIO
}

\author{
H Modjtahedi, ', SA Khelwatty', RS Kirk', AM Seddon', S Essapen ${ }^{2}$, CA Del Vecchio ${ }^{3}$, AJ Wong $^{3}$ and S Eccles $^{4}$ \\ 'School of Life Sciences, Kingston University London, Kingston-upon-Thames, Surrey KTI 2EE, UK; ${ }^{2}$ St Luke's Cancer Centre, Royal Surrey County NHS \\ Foundation Trust, Guildford, UK; ${ }^{3}$ Department of Neurosurgery, Stanford University Medical Centre, Stanford, CA, USA; ${ }^{4}$ Division of Cancer Therapeutics, \\ The Institute of Cancer Research, Sutton, UK
}

\begin{abstract}
BACKGROUND: The human epidermal growth factor receptor (EGFR) is an important therapeutic target in oncology, and three different types of EGFR inhibitors have been approved for the treatment of cancer patients. However, there has been no clear association between the expression levels of EGFR protein in the tumours determined by the FDA-approved EGFR PharmDx kit (Dako) or other standard anti-EGFR antibodies and the response to the EGFR inhibitors.

METHOD: In this study, we investigated the potential of our anti-EGFR monoclonal antibodies (mAbs; ICR9, ICRI0, ICRI6) for immunohistochemical diagnosis of wild-type EGFR and/or the type-III deletion mutant form of EGFR (EGFRvIII) in formalin-fixed, paraffin-embedded human tumour specimens.

RESULTS: We found that the anti-EGFR mAb in the EGFR PharmDx kit stained both wild-type and EGFRvlll-expressing cells in formalin-fixed, paraffin-embedded sections. This pattern of EGFR immunostaining was also found with our anti-EGFR mAb ICRI6. In contrast, mAbs ICRIO and ICR9 were specific for the wild-type EGFR.

CONCLUSION: We conclude that mAbs ICR9 and ICRIO are ideal tools for investigating the expression patterns of wild-type EGFR protein in tumour specimens using immunohistochemistry, and to determine their prognostic significance, as well as predictive value for response to therapy with EGFR antibodies.

British Journal of Cancer (2012) I 06, 883-888. doi:I0.1038/bjc.2012.27 www.bjcancer.com
\end{abstract}

Published online 7 February 2012

(c) 2012 Cancer Research UK

Keywords: ICRIO; EGFR; EGFRvIll; EGFR PharmDx; immunohistochemistry

The epidermal growth factor receptor (EGFR)/HER1 is a $170-\mathrm{KDa}$ transmembrane glycoprotein with tyrosine kinase activity and the prototype of the type-I growth factor receptor (also called HER/ ErbB) family, which can be activated following the binding of several ligands (EGF, TGF $\alpha$, amphiregulin, HB-EGF, betacellulin and epiregulin) to its extracellular domain (Carpenter, 1987; Modjtahedi and Dean, 1994; Salomon et al, 1995; Gullick, 2001; Singh and Harris, 2005). Ligand binding induces EGFR homodimerisation or heterodimerisation with other members of the ErbB family, autophosphorylation of tyrosine residues and ultimately, activation of several intracellular signalling pathways (Yarden and Sliwkowski, 2001). Signalling via the EGFR has been associated with increased cell proliferation, reduced apoptosis, angiogenesis, invasion and metastasis, and all of which are hallmarks of cancer (Yarden, 2001; Lui and Grandis, 2002; Hanahan and Weinberg, 2011). Aberrant expression and activation of EGFR have been reported in a wide range of epithelial tumours, and in several studies, have been associated with poor prognosis and resistance to therapy (Modjtahedi and Dean, 1994; Salomon et al, 1995; Nicholson et al, 2001).

\footnotetext{
*Correspondence: Dr H Modjtahedi;

E-mail: H.Modjtahedi@Kingston.ac.uk

Received 16 September 2011; revised 15 November 201 1; accepted 16 January 2012; published online 7 February 2012
}

The EGFR is an important therapeutic target in patients with metastatic colorectal cancer (mCRC), head and neck cancer, nonsmall cell lung cancer and pancreatic cancer (Mendelsohn and Baselga, 2003; Zhang et al, 2007; Ciardiello and Tortora, 2008; Modjtahedi and Essapen, 2009). Currently, two classes of EGFR inhibitors namely monoclonal antibodies (mAbs) and small molecules, which bind to the extracellular ligand-binding domain and the intracellular tyrosine kinase domain of the EGFR, respectively, have been approved for the treatment of cancer patients (Modjtahedi and Essapen, 2009). Of these, the mAbs cetuximab and panitumumab have been approved for the treatment of patients with mCRC in combination with chemotherapy, and several other anti-EGFR antibodies are currently at different stages of clinical development (Wong, 2005; Wu et al, 2008). To aid in the identification of CRC patients who are eligible for treatment with cetuximab and panitumumab, the EGFR status of the tumours is determined using the FDA-approved EGFR PharmDx immunohistochemistry kit (Dako, Cambridge, UK; Mitchell, 2004; Bhargava et al, 2006; Buckley and Kakar, 2007; Ensinger and Sterlacci, 2008). However, although treatment with these agents improve survival in mCRC patients, the duration of response is often limited and is only seen in a subset of patients (Schrag, 2004). In addition, there has been no clear association between the expression levels of EGFR in the tumours determined by the FDA-approved PharmDx kit or other commercial antiEGFR antibodies and the response to therapy or patient prognosis 
(Cunningham et al, 2004; Schrag, 2004; Chung et al, 2005; Bhargava et al, 2006; Derecskei et al, 2006; Hebbar et al, 2006; Bralet et al, 2007; Buckley and Kakar, 2007; Ensinger and Sterlacci, 2008; Modjtahedi and Essapen, 2009).

The increased signalling and cellular responses via the EGFR may be mediated by several mechanisms, including overexpression of wild-type EGFR, overproduction of EGFR ligands, deletion of part or all of the extracellular domain, somatic mutations of its intracellular tyrosine kinase domain and heterodimerisation with other members of the EGFR family (Yarden, 2001; Modjtahedi and Essapen, 2009). For example, the type-III deletion mutant form of EGFR (EGFRvIII) is the most common variant form of EGFR and has been detected on both the cell surface and in the cytoplasm of many cancer types, including colorectal, glioma, breast, ovary, prostate and lung cancer (Olapade-Olaopa et al, 2000; Tang et al, 2000; Cunningham et al, 2005). EGFRvIII is characterised by deletion of 267 amino acids in the external domain of the receptor, which consequently is ligand-independent, constitutively active and highly transforming (Sugawa et al, 1990; Wong et al, 1992). In addition, several useful anti-EGFRvIII-specific mAbs have been developed for investigating expression levels, subcellular location, biological and prognostic significance, predictive value, as well as for targeting human cancers (Wikstrand et al, 1995; Omidfar et al, 2004; Heimberger et al, 2005; Gupta et al, 2010). Unfortunately, antibodies that are used in the immunohistochemical detection of EGFR and determining its prognostic significance and predictive value are not specific to the wild-type EGFR and can also bind to the EGFRvIII (Modjtahedi and Essapen, 2009). To our knowledge, there is currently no comprehensive study examining the expression pattern, prognostic significance and predictive value of the wild-type EGFR protein with mAbs, which discriminate against the common EGFRvIII mutant. Such studies may lead to identification of a more defined subpopulation of CRC patients whose tumours are EGFR-dependent and may therefore be more sensitive to therapy with the EGFR-blocking antibodies (Meropol, 2005; Khambata-Ford et al, 2007; Modjtahedi and Essapen, 2009).

We have extensively profiled our unique panel of high affinity rat anti-EGFR mAbs for use in the diagnosis and therapy of human cancers (Modjtahedi et al, 1993, 2003; Dean et al, 1994). In this study, we investigated the potential of some of our antibodies (ICR9, ICR10, ICR16) for immunohistochemical diagnosis of the wild-type EGFR and/or the EGFRvIII in formalin-fixed, paraffinembedded human tumour specimens. We show that unlike the antibody in the EGFR PharmDx kit, mAbs ICR10 and ICR9 are specific for the wild-type EGFR, and therefore, these antibodies may form ideal tools for investigating the expression pattern, prognostic significance and predictive value of wild-type EGFR protein in human cancers.

\section{MATERIALS AND METHODS}

\section{Tumour cell lines and cell culture}

The human EGFR-overexpressing head and neck HN5 $\left(1.4 \times 10^{7}\right.$ EGFRs per cell) and breast carcinoma cell line MCF-7, which expresses undetectable levels of EGFR and EGFRvIII, were cultured routinely in Dulbecco's modified Eagle's medium (DMEM; Sigma, Poole, UK) supplemented with $10 \%$ fetal calf serum (Invitrogen, Loughborough, UK) and the antibiotics penicillin, streptomycin, neomycin as described previously (Cowley et al, 1984; Modjtahedi et al, 1993). As human cancer cell lines show loss of EGFRvIII expression under cell culture conditions (Lammering et al, 2004), HC2 $20 \mathrm{~d} 2 / \mathrm{c}$ was generated by transfection of NIH3T3 cells with cDNA encoding EGFRvIII, and these cells were employed as EGFRvIII-positive tumour $\left(\sim 2 \times 10^{6}\right.$ mutant receptors $)$ cell line (Moscatello et al, 1995). HC2 20d2/c cells were maintained in DMEM supplemented with $10 \%$ fetal calf serum and $350 \mu \mathrm{g} \mathrm{ml}^{-1}$
Geneticin (Invitrogen) as described previously (Moscatello et al, 1995). The paraffin-embedded primary human glioblastoma (GBM) tumour slides were acquired from the Neuropathology division of Stanford Medical Centre, with all patient identification removed.

\section{Antibodies}

The three anti-EGFR mAbs used in this study (ICR9, ICR10 and ICR16) were raised against three epitope clusters on the extracellular domain of the human EGFR, using the human head and neck carcinoma cell line HN5 as a source of immunogen (Modjtahedi et al, 1993). ICR9 binds to epitope 'A', ICR10 binds to epitope ' $B$ ', and ICR16 binds to epitope ' $C$ ' on the EGFR, respectively (Modjtahedi et al, 1993, 2003; Dean et al, 1994). The EGFR PharmDx kit, containing positive and negative control cell lines, was purchased from Dako. The mouse anti-human EGFRvIII mAb G100 was purchased from Zymed Life Technologies (Grand Island, NY, USA). The rabbit anti-rat HRP secondary antibody and FITCconjugated $\mathrm{F}\left(\mathrm{ab}^{\prime}\right) 2$ goat anti-rat IgG secondary antibody was purchased from ABD Serotec Ltd (Oxford, UK).

\section{Flow cytometry}

The cell surface expression of the growth factor receptors was determined using FACS analysis as described previously (Khelwatty et al, 2011). Briefly, approximately $1 \times 10^{6}$ HN5 or HC2 20d2/c cells in $1 \mathrm{ml}$ of DMEM/2\% FBS were incubated with primary antibodies or control medium or for $1 \mathrm{~h}$ by rotation at $4{ }^{\circ} \mathrm{C}$. Cells were washed three times by centrifugation for $5 \mathrm{~min}$ at 1000 r.p.m., and resuspended in DMEM/2\% FBS before incubation with FITC-conjugated $\mathrm{F}\left(\mathrm{ab}^{\prime}\right) 2$ goat anti-rat IgG secondary antibody. Following rotation for $1 \mathrm{~h}$ at $4{ }^{\circ} \mathrm{C}$, tumour cells were washed three more times, and the final cell pellet was resuspended in FACS Flow buffer (Becton Dickinson Ltd, Oxford, UK). A minimum of 10000 events were recorded by excitation with an argon laser at $488 \mathrm{~nm}$, and analysed using the FL-1 detector (FITC detector; $525 \mathrm{~nm}$ ) of a BD FACScalibur flow cytometer (Becton Dickinson Ltd) using CellQuest Pro software (Becton Dickinson Ltd).

\section{Cell pellet preparation, specimen fixation and paraffin embedding}

Cells were grown to near confluence in $170-\mathrm{cm}^{2}$ Nunc cell-culture flask as described above. The cell monolayer were detached by a cell scraper, transferred to a volumetric tube and centrifuged at 1600 r.p.m. for $5 \mathrm{~min}$. The resultant pellet was then fixed in $10 \%$ (v/v) neutral buffered formalin (Bios Europe Ltd, Skelmersdale, UK) for $45 \mathrm{~min}$. Sequentially, the pellet was dehydrated in a series of alcohols and cleared in histoclear, and then paraffin embedded (Paramat, VWR International Ltd, East Grinstead, UK). Tissue specimens were cut into sections of $5 \mu \mathrm{m}$ and mounted onto polyL-lysine-coated slides (Polysine, 631-0107, VWR International Ltd) for immunohistochemistry.

\section{EGFR PharmDx immunohistochemical staining}

EGFR PharmDx immunohistochemical staining was carried out manually according to the manufacturer's (Dako) protocol. Briefly, before staining, slides were deparaffinised and rehydrated. Protein $\mathrm{K}$ proteolytic digestion was then carried out and endogenous activity was blocked. Subsequently, slides were treated with primary antibody or negative-control reagent and incubated for $30 \mathrm{~min}$ in a humid chamber. After rinsing in wash buffer, the slides were then treated with labelled polymer, HRP, according to the manufacturer's instructions. Finally, the slides were treated with diaminobenzidine substrate-chromogen solution (Dako), followed by counterstaining with haematoxylin and mounting in DPX mounting medium. 


\section{BJC $\Omega$}

\section{Immunostaining with anti-EGFR mAbs ICR9, ICR10 and ICR16}

As before, the slides were deparaffinised in histoclear and rehydrated in series of graded alcohols. The endogenous peroxidase activity was then blocked by incubation in 3\% hydrogen peroxide. Non-specific binding was blocked by incubating the slides in normal rabbit serum for $20 \mathrm{~min}$ in a humidity chamber. After blotting off the excess serum, each slide was incubated with $100 \mu \mathrm{l}$ primary antibody or TBS for $1 \mathrm{~h}$ at room temperature. Slides were then rinsed with TBS and incubated with rabbit anti-rat antibody HRP secondary antibody for $30 \mathrm{~min}$ at room temperature. Finally, the slides were treated with diaminobenzidine substrate-chromogen solution, followed by counterstaining with haematoxylin and mounting in DPX mounting fluid.
Detection of wild-type EGFR by ICR I0

$\mathrm{H}$ Modjtahedi et al

\section{RESULTS}

The anti-EGFR antibody clone 2-18C9 from the FDA-approved EGFR PharmDx kit was used for immunohistochemical staining of the human head and neck carcinoma cell line HN5 pellet $\left(1.4 \times 10^{7}\right.$ wild-type EGFR per cell) and HC2 20d2/c $\left(1.2 \times 10^{6}\right.$ EGFRvIII per cell) cell pellets. As shown in Figure 1, the antibody in the EGFR PharmDx kit binds strongly to both wild-type EGFR on HN5 cells and EGFRvIII on HC2 $20 \mathrm{~d} 2 / \mathrm{c}$ cells in formalin-fixed, paraffinembedded sections. There was no staining of EGFR-negative CAMA-1 cells with antibody clone 2-18C9 (data not shown).

Next, we performed immunohistochemical staining of HN5 and HC2 20d2/c cell pellets using three rat anti-EGFR mAbs: ICR9, ICR10 and ICR16 (Modjtahedi et al, 1993, 2003). Unlike the antiEGFR antibody 2-18C9 in the EGFR PharmDx kit (Figure 1), mAbs
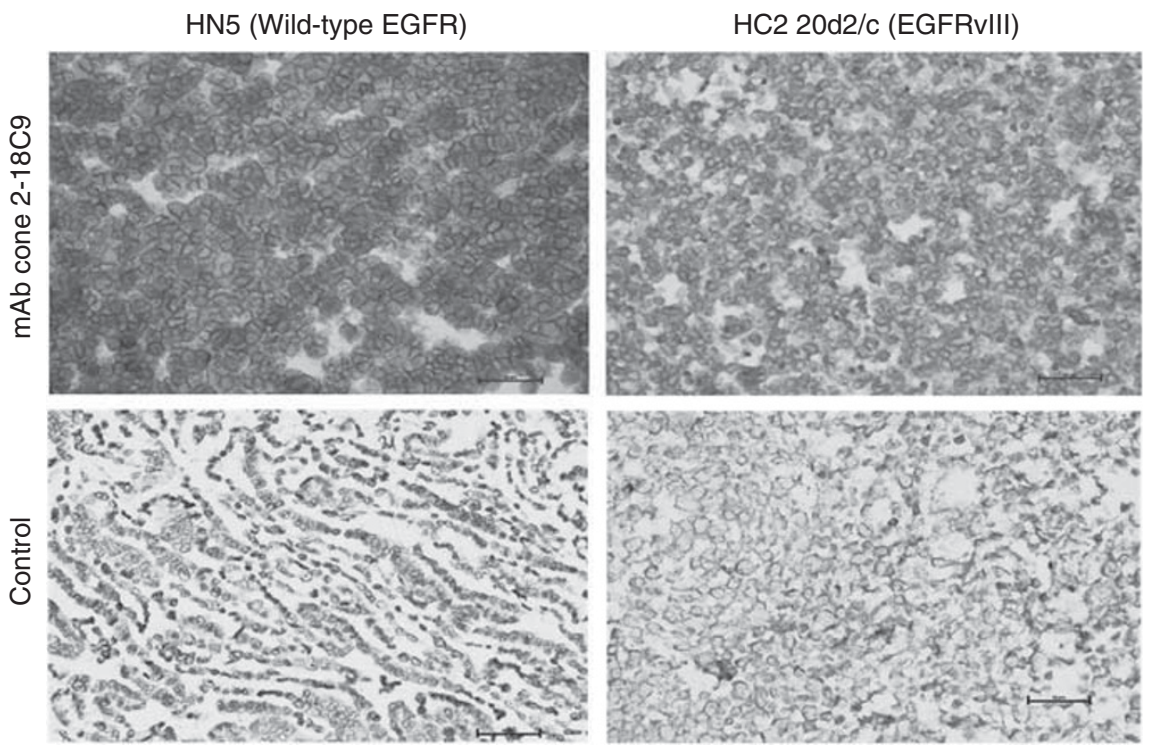

Figure I Immunohistochemical staining of formalin-fixed, paraffin-embedded HN5 and HC2 20d2/c cells, using the EGFR PharmDx primary antibody Clone 2-18C9 and negative control. EGFR staining was carried out manually according to the manufacturer's (Dako) protocol.
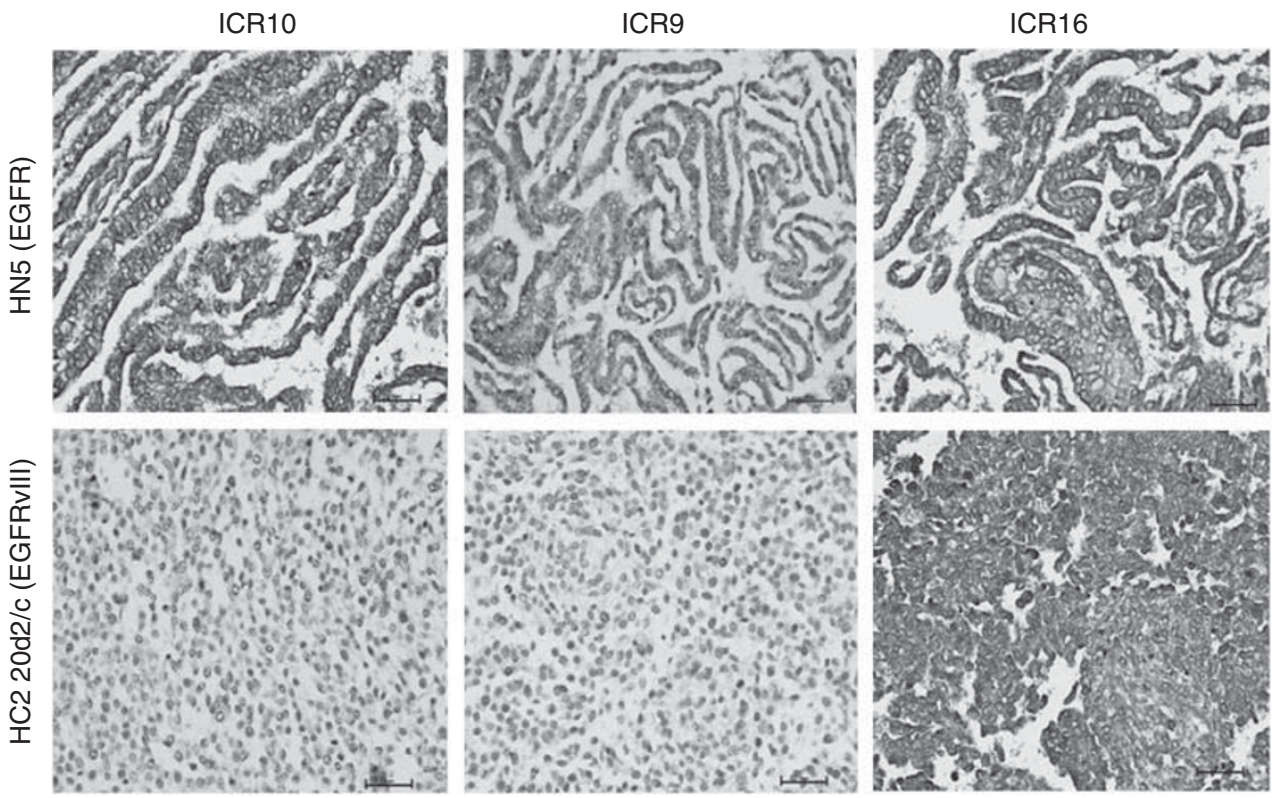

Figure 2 Immunohistochemical staining of formalin-fixed, paraffin-embedded HN5 and HC2 20d2/c cell pellets, using our anti-EGFR mAbs ICRI0, ICR9 and ICRI6, and negative control, as described in the 'Materials and Methods' section. 
ICR9 and ICR10 are specific for the wild-type EGFR and do not stain the EGFRvIII in formalin-fixed, paraffin-embedded tumour specimens (Figure 2). However, like antibody clone $2-18 \mathrm{C} 9, \mathrm{mAb}$ ICR 16 stained both HN5 and HC2 20d2/c cells and can therefore be used for immunohistochemical detection of both wild-type EGFR and EGFRvIII in paraffin-embedded fixed tissues (Figure 2). The specificity of ICR10 for the wild-type EGFR was also demonstrated by flow cytometry and the results as presented in Table 1 .

Finally, we examined the diagnostic potential of mAb ICR10 for immunohistochemical detection of wild-type EGFR in formalinfixed, paraffin-embedded tissue. We stained tissue from a tumour that was EGFRvIII positive, but wild-type EGFR-negative with ICR10 and an antibody specific for EGFRvIII (G100; Figure 3). This revealed staining by the G100, but not the ICR10. On the other hand, using these same antibodies to stain a tumour that is EGFRvIIInegative but wild-type EGFR-positive showed labelling of the tumour by ICR10, but not G100. These results demonstrate that ICR10 can be used to specifically label wild-type EGFR in pathology specimens.

\section{DISCUSSION}

Despite the approval of several EGFR inhibitors for the treatment of human cancers, there has been no clear association between the

Table I MFI for binding of anti-EGFR mAbs ICRIO and ICRI 6 to the EGFRoverexpressing HN5 and EGFRvlll-overexpressing (HC2 20d2/c) cell lines

\begin{tabular}{lrr}
\hline & \multicolumn{2}{c}{ MFI } \\
\cline { 2 - 3 } Antibody & HN5 & HC220d2/c \\
\hline Control & 6.87 & 5.04 \\
ICRI0 & 1092.45 & 3.55 \\
ICRI6 & 1189.75 & 593.05 \\
\hline
\end{tabular}

Abbreviations: EGFR = epidermal growth factor receptor; EGFRvIII = type-III deletion mutant form of EGFR; $m A b s=$ monoclonal antibodies; $M F I=$ mean fluorescence intensity. expression levels of EGFR in the tumours determined by the FDAapproved EGFR PharmDx kit (Dako) or other standard anti-EGFR antibodies and the response to the EGFR inhibitors (Arteaga, 2002; Cunningham et al, 2004; Chung et al, 2005; Tos and Ellis, 2005; Derecskei et al, 2006; Hebbar et al, 2006; Bralet et al, 2007; Buckley and Kakar, 2007; Modjtahedi and Essapen, 2009; Hecht et al, 2010). In some studies, the presence of somatic mutations of KRAS, $B R A F, \quad P I 3 K C A$ and loss of PTEN in tumours (i.e., EGFRindependent tumours) were associated with primary resistance, whereas other studies found an association between the EGFR gene amplification, high levels of EGFR ligands such as amphiregulin and epiregulin, and sensitivity to therapy with anti-EGFR mAbs (Amado et al, 2008; Cappuzzo et al, 2008; Di Nicolantonio et al, 2008; Jacobs et al, 2009; Modjtahedi and Essapen, 2009; Bardelli and Siena, 2010; De Roock et al, 2010; Oliveras-Ferraros et al, 2010). Of all the markers, only KRAS genotyping is performed routinely to exclude patients, whose tumours contain KRAS mutations, from receiving anti-EGFR therapy (Allegra et al, 2009; Siena et al, 2009). In addition, clinical benefit is not seen in all mCRC patients with wild-type KRAS, and there is a need for the identification of more reliable predictive markers for use in the selection of patients whose tumours are EGFR-dependent and will therefore benefit from therapy with EGFR-blocking antibodies.

In CRC, the percentage of EGFR-positive cases reported in the literature ranged from 8 to $100 \%$ of the cases examined. In addition, there are also conflicting data regarding the correlation between the EGFR protein expression in the primary tumour and its related metastases, and their prognostic significance and predictive value (Scartozzi et al, 2004; Chung et al, 2005; Ljuslinder et al, 2009). This wide variation may be due to the usage of different antibodies, tumour specimen source (e.g., primary tumour and/or related metastasis), scoring system, choice of fixative, storage time and patient subpopulations (Atkins et al, 2004; Scartozzi et al, 2004; Cunningham et al, 2005; Meropol, 2005; Perez-Soler and Saltz, 2005; Hebbar et al, 2006; Penault-Llorca et al, 2006; Bralet et al, 2007; Buckley and Kakar, 2007; Ljuslinder et al, 2009; Modjtahedi and Essapen, 2009; Bardelli and Siena, 2010; Yarom et al, 2010). In addition, antibodies which are
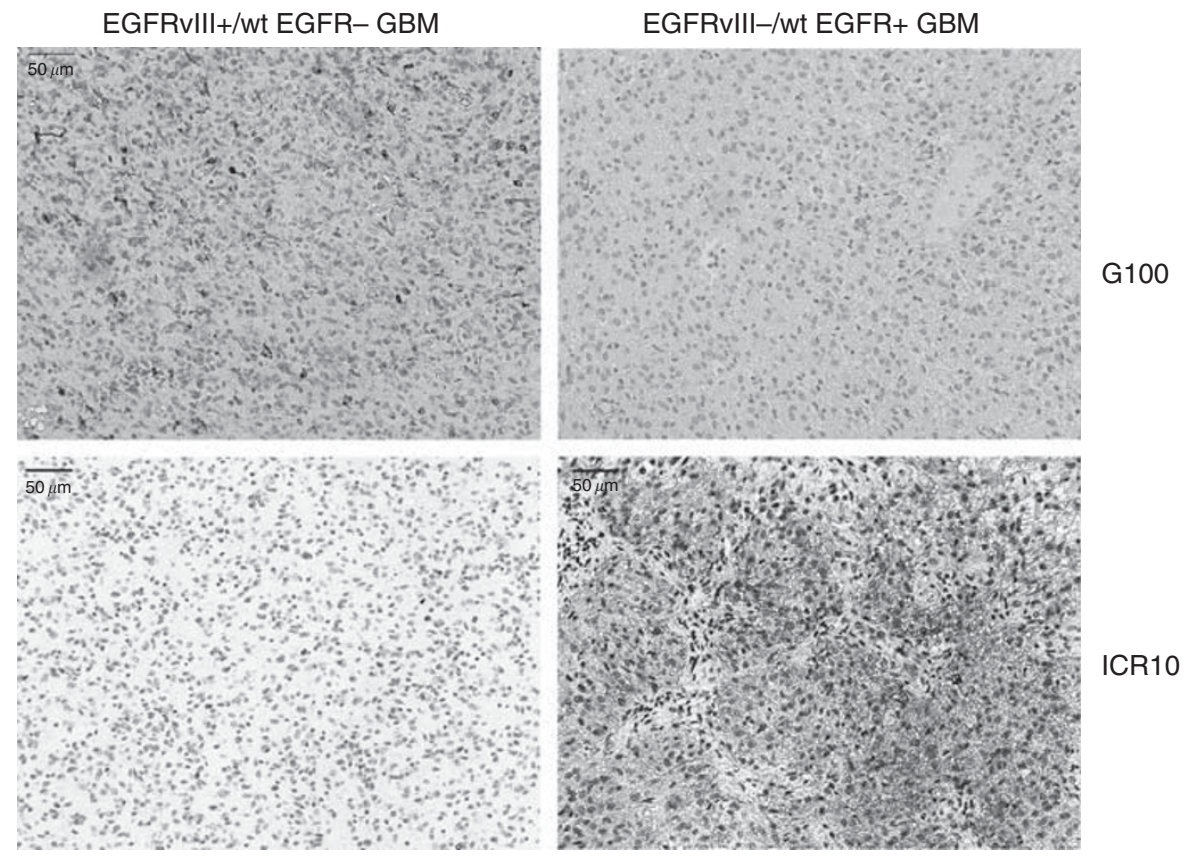

Figure 3 Differential staining of tumours containing wild-type EGFR vs EGFRvIll by ICR I0. A primary human glioblastoma tumour positive for EGFRvIII, but lacking EGFR expression (EGFRvIII + /wt EGFR-GBM) was stained by immunohistochemistry using either GI00 (specific for EGFRvIll only) or ICRIO. A second glioblastoma tumour that was negative for EGFRvIll, but positive for wt EGFR (EGFRvIII-/wt EGFR +) was also stained with GIO0 and ICRI0. 
routinely used in the immunohistochemical detection of EGFR and to determine its prognostic significance and predictive value for response to therapy with the EGFR inhibitors are not specific to the wild-type EGFR and can also bind to the EGFRvIII. Indeed, in this study, we have shown that the FDA-approved antibody in the EGFR PharmDx kit (Dako), which is used in the selection of EGFRpositive cancer patients for therapy with anti-EGFR mAbs, is not specific to the wild-type EGFR protein and can also bind to the EGFRvIII in formalin-fixed, paraffin-embedded tissues (Figure 1). Our anti-EGFR mAb ICR16 can also bind to both EGFR and EGFRvIII in formalin-fixed, paraffin-embedded tissues. We have reported previously that in comparison with mAbs ICR9 and ICR 10, mAb ICR16 was very effective in (1) blocking the binding of ligands to the EGFR, (2) inhibiting the tyrosine phosphorylation of EGFR and downstream cell signalling molecules, and (3) inhibiting the growth of in vitro and in vivo of EGFR-overexpressing tumour cell lines (Modjtahedi et al, 1993, 2003; Dean et al, 1994; Modjtahedi and Dean, 1994). Interestingly, unlike mAbs clone 2-18C9 and ICR16, we have shown here that mAbs ICR10 and ICR9 are specific for the wild-type EGFR and can therefore be used for immunohistochemical detection of wild-type EGFR in formalinfixed, paraffin-embedded tissues (Figures 1-3).

\section{REFERENCES}

Allegra CJ, Jessup JM, Somerfield MR, Hamilton SR, Hammond EH, Hayes DF, McAllister PK, Morton RF, Schilsky RL (2009) American Society of Clinical Oncology provisional clinical opinion: testing for KRAS gene mutations in patients with metastatic colorectal carcinoma to predict response to anti-epidermal growth factor receptor monoclonal antibody therapy. J Clin Oncol 27(12): 2091-2096

Amado RG, Wolf M, Peeters M, Van Cutsem E, Siena S, Freeman DJ, Juan T, Sikorski R, Suggs S, Radinsky R, Patterson SD, Chang DD (2008) Wild-type KRAS is required for panitumumab efficacy in patients with metastatic colorectal cancer. J Clin Oncol 26(10): 1626-1634

Arteaga CL (2002) Epidermal growth factor receptor dependence in human tumors: more than just expression? Oncologist 7(Suppl 4): 31-39

Atkins D, Reiffen KA, Tegtmeier CL, Winther H, Bonato MS, Storkel S (2004) Immunohistochemical detection of EGFR in paraffin-embedded tumor tissues: variation in staining intensity due to choice of fixative and storage time of tissue sections. J Histochem Cytochem 52(7): 893-901

Bardelli A, Siena S (2010) Molecular mechanisms of resistance to cetuximab and panitumumab in colorectal cancer. J Clin Oncol 28(7): 1254-1261

Bhargava R, Chen B, Klimstra DS, Saltz LB, Hedvat C, Tang LH, Gerald W, Teruya-Feldstein J, Paty PB, Qin J, Shia J (2006) Comparison of two antibodies for immunohistochemical evaluation of epidermal growth factor receptor expression in colorectal carcinomas, adenomas, and normal mucosa. Cancer 106(8): $1857-1862$

Bralet MP, Paule B, Falissard B, Adam R, Guettier C (2007) Immunohistochemical variability of epidermal growth factor receptor (EGFR) in liver metastases from clonic carcinomas. Histopathology 50: 210-216

Buckley AF, Kakar S (2007) Comparison of the Dako EGFR pharmDx kit and Zymed EGFR antibody for assessment of EGFR status in colorectal adenocarcinoma. Appl Immunohistochem Mol Morphol 15(3): $305-309$

Cappuzzo F, Finocchiaro G, Rossi E, Janne PA, Carnaghi C, Calandri C, Bencardino K, Ligorio C, Ciardiello F, Pressiani T, Destro A, Roncalli M, Crino L, Franklin WA, Santoro A, Varella-Garcia M (2008) EGFR FISH assay predicts for response to cetuximab in chemotherapy refractory colorectal cancer patients. Ann Oncol 19(4): 717-723

Carpenter G (1987) Receptors for epidermal growth factor and other polypeptide mitogens. Annu Rev Biochem 56: $881-914$

Chung KY, Shia J, Kemeny NE (2005) Cetuximab shows activity in colorectal cancer patients with tumours that do not express the epidermal growth factor receptor by immunohistochemistry. J Clin Oncol 23: $1803-1810$

Ciardiello F, Tortora G (2008) EGFR antagonists in cancer treatment. $N$ Engl J Med 358(11): $1160-1174$

Cowley G, Smith JA, Gusterson B, Hendler F, Ozanne B (1984) The amount of EGF receptor is elevated on human squamous cell carcinoma. Cancer Cells 1: $5-10$
In summary, at present, eligible patients for therapy with cetuximab and panitumumab, in addition to wild-type KRAS, should express cell surface EGFR in their tumours, using the FDAapproved Dako EGFR PharmDx immunohistochemistry kit or other anti-EGFR antibodies. However, such antibodies do not discriminate between the ligand-independent and constitutively active EGFRvIII, and wild-type EGFR and somatic mutation of the EGFR intracellular tyrosine kinase domain is rare in patients with mCRC (Lee et al, 2005). We conclude that mAbs ICR9 and ICR10 are ideal tools for investigating the expression level and the cellular location of wild-type EGFR in formalin-fixed, paraffinembedded tumour specimens using immunohistochemistry, and to unravel its prognostic significance as well as predictive value for response to therapy with the EGFR-blocking antibodies in future studies.

\section{ACKNOWLEDGEMENTS}

We acknowledge the support of MRC (UK), Cancer Research UK, BRIGHT Charity (UK), Institute of Cancer Research (UK) and Kingston University London (UK).
Cunningham D, Humblet Y, Siena S, Khayat D, Bleiberg H, Santoro A, Bets D, Mueser M, Harstrick A, Verslype C, Chau I, Van Cutsem E (2004) Cetuximab Monotherapy and Cetuximab plus Irinotecan in IrinotecanRefractory Metastatic Colorectal Cancer. N Engl J Med 351(4): 337 - 345 Cunningham MP, Essapen S, Thomas H, Green M, Lovell DP, Topham C, Marks C, Modjtahedi H (2005) Coexpression, prognostic significance and predictive value of EGFR, EGFRvIII and phosphorylated EGFR in colorectal cancer. Int J Oncol 27: 317-325

De Roock W, Claes B, Bernasconi D, De Schutter J, Biesmans B, Fountzilas G, Kalogeras KT, Kotoula V, Papamichael D, Laurent-Puig P, PenaultLlorca F, Rougier P, Vincenzi B, Santini D, Tonini G, Cappuzzo F, Frattini M, Molinari F, Saletti P, De Dosso S, Martini M, Bardelli A, Siena S, Sartore-Bianchi A, Tabernero J, Macarulla T, Di Fiore F, Gangloff AO, Ciardiello F, Pfeiffer P, Qvortrup C, Hansen TP, Van Cutsem E, Piessevaux H, Lambrechts D, Delorenzi M, Tejpar S (2010) Effects of KRAS, BRAF, NRAS, and PIK3CAmutations on the efficacy of cetuximab plus chemotherapy in chemotherapy-refractory metastatic colorectal cancer: a retrospective consortium analysis. Lancet Oncol 11(8): $753-762$

Dean C, Modjtahedi H, Eccles S, Box G, Styles J (1994) Immunotherapy with antibodies to the EGF receptor. Int J Cancer Suppl 8: 103-107

Derecskei K, Moldvay J, Bogos K, Timari J (2006) Protocol modifications influence the result of EGF receptor immunodetection by EGFR pharmdx in paraffin-embedded cancer tissues. Pathol Oncol Res 12(4): $241-245$

Di Nicolantonio F, Martini M, Molinari F, Sartore-Bianchi A, Arena S, Saletti P, De Dosso S, Mazzucchelli L, Frattini M, Siena S, Bardelli A (2008) Wildtype BRAF is required for response to panitumumab or cetuximab in metastatic colorectal cancer. J Clin Oncol 26(35): 5705-5712

Ensinger C, Sterlacci W (2008) Implications of EGFR Pharmdx Kit for cetuximab eligibility. Expert Rev Mol Diagn 2: $141-148$

Gullick W (2001) The Type 1 growth factor receptors and their ligands considered as a complex system. Endocr Relat Cancer 8(2): 75-82

Gupta P, Han SY, Holgado-Madruga M, Mitra SS, Li G, Nitta RT, Wong AJ (2010) Development of an EGFRvIII specific recombinant antibody. BMC Biotechnol 10: 72

Hanahan D, Weinberg RA (2011) Hallmarks of cancer: the next generation. Cell. 144(5): 646-674

Hebbar M, Wacrenier A, Desauw C, Romano O, Cattan S, Triboulet JP, Pruvot FR (2006) Lack of usefulness of epidermal growth factor receptor expression determination for cetuximab therapy in patients with colorectal cancer. Anticancer Drugs 17(7): 855-857

Hecht JR, Mitchell E, Neubauer MA, Burris Iii HA, Swanson P, Lopez T, Buchanan G, Reiner M, Gansert J, Berlin J (2010) Lack of correlation between epidermal growth factor receptor status and response to panitumumab monotherapy in metastatic colorectal cancer. Clin Cancer Res 16(7): $2205-2213$ 
Heimberger AB, Hlatky R, Suki D, Yang D, Weinberg J, Gilbert M, Sawaya R, Aldape K (2005) Prognostic effect of epidermal growth factor receptor and EGFRvIII in glioblastoma multiforme patients. Clin Cancer Res 11(4): $1462-1466$

Jacobs B, De Roock W, Piessevaux H, Van Oirbeek R, Biesmans B, De Schutter J, Fieuws S, Vandesompele J, Peeters M, Van Laethem JL, Humblet Y, Penault-Llorca F, De Hertogh G, Laurent-Puig P, Van Cutsem E, Tejpar S (2009) Amphiregulin and epiregulin mRNA expression in primary tumors predicts outcome in metastatic colorectal cancer treated with cetuximab. J Clin Oncol 27(30): 5068-5074

Khambata-Ford S, Garrett CR, Meropol NJ, Basik M, Harbison CT, Wu S, Wong TW, Huang X, Takimoto CH, Godwin AK, Tan BR, Krishnamurthi SS, Burris III HA, Poplin EA, Hidalgo M, Baselga J, Clark EA, Mauro DJ (2007) Expression of epiregulin and amphiregulin and K-ras mutation status predict disease control in metastatic colorectal cancer patients treated with cetuximab. J Clin Oncol 25(22): 3230-3237

Khelwatty SA, Essapen S, Seddon AM, Modjtahedi H (2011) Growth response of human colorectal tumour cell lines to treatment with afatinib (BIBW2992), an irreversible erbB family blocker, and its association with expression of HER family members. Int J Oncol 39: 483-491

Lammering G, Valerie K, Lin PS, Hewit TH, Schmidt-Ullrich RK (2004) Radiation-induced activation of a common variant of EGFR confers enhanced radioresistance. Radiother Oncol 72(3): 267-273

Lee JW, Soung YH, Kim SY, Park WS, Nam SW, Lee JY, Yoo NJ, Lee SH (2005) Absence of EGFR mutation in the kinase domain in common human cancers besides non-small cell lung cancer. Int J Cancer 113(3): $510-511$

Ljuslinder I, Malmer B, Isaksson-Mettävainio M, Öberg $\AA$, Henriksson R, Stenling R, Palmqvist R (2009) ErbB 1-4 expression alterations in primary colorectal cancers and their corresponding metastases. Anticancer Res 29(5): $1489-1494$

Lui VW, Grandis JR (2002) EGFR-mediated cell cycle regulation. Anticancer Res 22(1A): $1-11$

Mendelsohn J, Baselga J (2003) Status of epidermal growth factor receptor antagonists in the biology and treatment of cancer. J Clin Oncol 21(14): $2787-2799$

Meropol NJ (2005) Epidermal growth factor receptor inhibitors in colorectal cancer: it's time to get back on target. J Clin Oncol 23(9): 1791-1793

Mitchell P (2004) Erbitux diagnostic latest adjunct to cancer therapy. Nat Biotechnol 22(4): $363-364$

Modjtahedi H, Dean C (1994) The receptor for EGF and its ligands: expression, prognostic value, and target for therapy in cancer. Int J Onco 4: $277-296$

Modjtahedi H, Essapen S (2009) Epidermal growth factor receptor inhibitors in cancer treatment: advances, challenges and opportunities. Anticancer Drugs 20: $851-855$

Modjtahedi H, Moscatello DK, Box G, Green M, Shoton C, Lamb DJ, Reynolds LJ, Wong AJ, Dean C, Thomas H, Eccles S (2003) Targeting of cells expressing wild-type EGFR and type-III mutant EGFR (EGFR VIII) by anti-EGFR MAB ICR62: a two-pronged attack for tumour therapy. Int J Cancer 105: 273-280

Modjtahedi H, Styles JM, Dean CJ (1993) The human EGF receptor as a target for cancer therapy: six new rat mAbs against the receptor on the breast carcinoma MDA-MB 468. Br J Cancer 67: 247-253

Moscatello DK, Holgado-Madruga M, Godwin AK, Ramirez G, Gunn G, Zoltick PW, Biegel JA, Hayes RL, Wong AJ (1995) Frequent expression of a mutant epidermal growth factor receptor in multiple human tumors. Cancer Res 55(23): 5536-5539

Nicholson RI, Gee JW, Harper ME (2001) EGFR and cancer prognosis. Eur J Cancer 37: 9-15

Olapade-Olaopa EO, Moscatello DK, MacKay EH, Horsburgh T, Sandhu DP, Terry TR, Wong AJ, Habib FK (2000) Evidence for the differential expression of a variant EGF receptor protein in human prostate cancer. Br J Cancer 82(1): $186-194$

Oliveras-Ferraros C, Vall-Llovera AM, Salip DC, Vazquez-Martin A, Cufi S, Queralt B, Martin-Castillo B, Brunet J, de Llorens R, Menendez JA (2010) Evolution of the predictive markers amphiregulin and epiregulin mRNAs during long-term cetuximab treatment of KRAS wild-type tumor cells. Invest New Drugs; DOI:10.1007/s10637-010-9612-2
Omidfar K, Rasaee MJ, Modjtahedi H, Forouzandeh M, Taghikhani M, Bakhtiari A, Paknejad M, Kashanian S (2004) Production and characterization of a new antibody specific for the mutant EGF receptor, EGFRvIII, in Camelus bactrianus. Tumour Biol 25(4): 179-187

Penault-Llorca F, Cayre A, Arnould L, Bibeau F, Bralet MP, Rochaix P, Savary J, Sabourin JC (2006) Is there an immunohistochemical technique definitively valid in epidermal growth factor receptor assessment? Oncol Rep 16(6): $1173-1179$

Perez-Soler R, Saltz L (2005) Cutaneous adverse effects with HER1/EGFRtargeted agents: is there a silver lining? J Clin Oncol 23(22): 5235-5246

Salomon DS, Bradt R, Ciardiello F, Normano N (1995) Epidermal growth factor-related peptides and their receptors in human malignancies. Crit Rev Oncol Hematol 19: 183-232

Scartozzi M, Bearzi I, Berardi R, Mandolesi A, Fabris G, Cascinu S (2004) Epidermal growth factor receptor (EGFR) status in primary colorectal tumors does not correlate with EGFR expression in related metastatic sites: Implications for treatment with EGFR-targeted monocolonal antibodies. J Clin Oncol 22(23): 4772-4778

Schrag D (2004) The price tag on progress - chemotherapy for colorectal cancer. N Engl J Med 351(4): 317-319

Siena S, Sartore-Bianchi A, Di Nicolantonio F, Balfour J, Bardelli A (2009) Biomarkers predicting clinical outcome of epidermal growth factor receptor-targeted therapy in metastatic colorectal cancer. J Natl Cancer Inst 101(19): $1308-1324$

Singh AB, Harris RC (2005) Autocrine, paracrine and juxtacrine signaling by EGFR ligands. Cell Signal 17(10): 1183-1193

Sugawa N, Ekstrand AJ, James CD, Collins VP (1990) Identical splicing of aberrant epidermal growth factor receptor transcripts from amplified rearranged genes in human glioblastomas. Proc Natl Acad Sci USA 87(21): $8602-8606$

Tang CK, Gong XQ, Moscatello DK, Wong AJ, Lippman ME (2000) Epidermal growth factor receptor vIII enhances tumorigenicity in human breast cancer. Cancer Res 60(11): 3081-3087

Tos APD, Ellis I (2005) Assessing epidermal growth factor receptor expression in tumours: What is the value of current test methods? Eur J Cancer (Oxford, England: 1990) 41(10): 1383-1392

Wikstrand CJ, Hale LP, Batra SK, Hill ML, Humphrey PA, Kurpad SN, McLendon RE, Moscatello D, Pegram CN, Reist CJ, Traweek ST, Wong AJ, Zalutsky MR, Bigner DD (1995) Monoclonal antibodies against EGFRvIII are tumor specific and react with breast and lung carcinomas and malignant gliomas. Cancer Res 55(14): 3140-3148

Wong AJ, Ruppert JM, Bigner SH, Grzeschik CH, Humphrey PA, Bigner DS, Vogelstein B (1992) Structural alterations of the epidermal growth factor receptor gene in human gliomas. Proc Natl Acad Sci USA 89(7): $2965-2969$

Wong S (2005) Cetuximab: an epidermal growth factor receptor monoclonal antibody for the treatment of colorectal cancer. Clin Ther 27: 684-694

Wu M, Rivkin A, Pham T (2008) Panitumumab: Human monoclonal antibody against epidermal growth factor receptor for the treatment of metastatic colorectal cancer. Clin Ther 30: 14-29

Yarden Y (2001) The EGFR family and its ligands in human cancer: signalling mechanisms and therapeutic opportunities. Eur J Cancer 37(Supplement 4): 3-8

Yarden Y, Sliwkowski MX (2001) Untangling the ErbB signalling network. Nat Rev Mol Cell Biol 2(2): 127-137

Yarom N, Marginean C, Moyana T, Gorn-Hondermann I, Birnboim HC, Marginean H, Auer RC, Vickers M, Asmis TR, Maroun J, Jonker D (2010) EGFR expression variance in paired colorectal cancer primary and metastatic tumors. Cancer Biol Ther 10(5): 416-421

Zhang H, Berezov A, Wang Q, Zhang G, Drebin J, Murali R, Greene MI (2007) ErbB receptors: from oncogenes to targeted cancer therapies. J Clin Invest 117(8): 2051-2058

cC)(-) (2) This work is licensed under the Creative Commons BY NG SA Attribution-NonCommercial-Share Alike 3.0 Unported License. To view a copy of this license, visit http://creativecommons. org/licenses/by-nc-sa/3.0/ 